\title{
FINANCIAL RESOURCES OF DOMESTIC ENTERPRISES: PROBLEMS OF FORMATION AND EFFICIENT USE
}

\author{
○2019 YASINOVSKA I. F., BEI I. M.
}

UDC 336.64

JEL: G32; R51

\section{Yasinovska I. F., Bei I. M. Financial Resources of Domestic Enterprises: Problems of Formation and Efficient Use}

The article is aimed at exploring the sources of financing for domestic enterprises, including by the types of economic activity; evaluating the dynamics of volume and structure of financial resources of Ukrainian enterprises, their financial results; finding directions to optimize the formation and efficiency of use of the financial resources of enterprises. The dynamics of the financial resources' structure of large and medium-sized enterprises in Ukraine as of March 31 for the time period of 2017-2019 are analyzed, the sources of their formation are estimated by the types of economic activity, dynamics of the financial results are analyzed. The main problems of the formation of financial resources in domestic enterprises are defined and ways of optimizing the formation and use of financial resources in the enterprises are proposed.

Keywords: financial resources, enterprise, sources of formation of financial assets, equity capital, borrowed capital, analysis, management. DOI: https://doi.org/10.32983/2222-4459-2019-9-259-264

Fig.: 1. Tabl.: 2. Bibl.: 8.

Yasinovska I. F. - PhD (Economics), Associate Professor, Associate Professor of the Department of State and Local Finance, Ivan Franko National University of Lviv (1 Universytetska Str., Lviv, 79000, Ukraine)

E-mail: i-yasenovska@ukr.net

ORCID: http://orcid.org/0000-0002-2766-8700

Bei I. M. - Master, Department of State and Local Finance, Ivan Franko National University of Lviv (1 Universytetska Str., Lviv, 79000, Ukraine) E-mail: iryskabey@gmail.com

УДК 336.64

JEL: G32; R51

Ясіновська І. Ф., Бей І. М. Фінансові ресурси вітчизняних підприємств: проблеми формування та ефективного використання Цілями статті $\epsilon$ дослідження джерел фінансування діяльності вітчизняних підприємств, зокрема за видами економічної діяльності; очінка динаміки обсягу та структури фінансових ресурсів підприємств України, їх фінансових результатів; пошук напрямів з оптимізації формування та підвищення ефективності використання фінансових ресурсів підприємств. Проаналізовано динаміку структури фінансових ресурсів великих і середніх підприємств України станом на 31 березня за період 2017-2019 рр. за видами економічної діяльності, надано оиінку джерел іх формування, а також проведено аналіз динаміки фінансових результатів. Визначено основні проблеми формування фінансових ресурсів вітчизняних підприємств і запропоновано шляхи оптимізації формування та ефективного використання фінансових ресурсів на підприємствах. Ключові слова: фінансові ресурси, підприємство, джерела формування фінансових ресурсів, власний капітал, позичковий капітал, аналіз, управління.

Рис.: 1. Табл.: 2. Бібл.: 8.

Ясіновська Ірина Фантинівна - кандидат економічних наук, доцент дочент кафедри державних та місцевих фінансів, Львівський національний університет імені Івана франка (вул. Університетська, 1 , Львів, 79000, Україна)

E-mail: i-yasenovska@ukr.net

ORCID: http://orcid.org/0000-0002-2766-8700

Бей Ірина Михайлівна - магістр кафедри державних та місцевих фінансів, Львівський начіональний університет імені Івана Франка (вул. Університетська, 1, Львів, 79000, Україна)

E-mail: iryskabey@gmail.com
УДК 336.64

JEL: G32; R51

Ясиновская И. Ф., Бэй И. М. Финансовые ресурсы отечественных предприятий: проблемы формирования и использования Целями статьи являются исследование источников финансирования деятельности отечественных предприятий, в том числе по видам экономической деятельности; оценка динамики объема и структуры финансовых ресурсов предприятий Украины, их финансовых результатов; поиск направлений по оптимизации формирования и повышению эффективности использования финансовых ресурсов предприятий. Проанализирована динамика структуры финансовых ресурсов крупных и средних предприятий Украины по состоянию на 31 марта за период 2017-2019 г2. по видам экономической деятельности, дана оченка источников их формирования, а также проведен анализ динамики финансовых результатов. Определены основные проблемы формирования финансовых ресурсов отечественных предприятий и предложены пути оптимизации формирования и использования финансовых ресурсов на предприятиях.

Ключевые слова: финансовые ресурсы, предприятие, источники формирования финансовых ресурсов, собственный капитал, заемный капитал, анализ, управление.

Рис.: 1. Табл.: 2. Библ.: 8.

Ясиновская Ирина Фантиновна - кандидат экономических наук, доцент, доцент кафедры государственных и местных финансов, Львовский национальный университет имени Ивана Франко (ул. Университетская, 1, Львов, 79000, Украина)

E-mail: i-yasenovska@ukr.net

ORCID: http://orcid.org/0000-0002-2766-8700

Бэй Ирина Михайловна - магистр кафедры государственных и местных финансов, Львовский национальный университет имени Ивана Франко (ул. Университетская, 1, Львов, 79000, Украина)

E-mail: iryskabey@gmail.com
$\mathrm{U}$ nder conditions of formation and development of market relations in Ukraine, the independence of enterprises, their economic and legal responsibility, the value of their financial stability increase. At the same time, many business entities face a lack of fi- nancial resources, which adversely affects their production and economic activity. In particular, arrears of enterprises to counterparties are emerging and increasing, financing opportunities for their further development are decreasing and tax budget revenues are declining. In 
these circumstances, the formation of sufficient financial resources and their optimal use is important for the implementation of financial and economic activity of Ukrainian enterprises.

Financial resources occupy a special place in management of an enterprise since their quality determines the continuity of the manufacturing and sale of the enterprise's products, its liquidity, solvency and profitability. It is well known that the availability of sufficient financial resources is a prerequisite for successful functioning of any business structure, thus analyzing sources of formation of financial resources and their optimization is of particular relevance.

The issues of formation and use of enterprise financial resources were studied by a number of domestic and foreign scientists, including: M. D. Bilyk, I. O. Blank, O.P.Blyzniuk, O.D. Vasylyk, A.P.Horpynchenko, I.V.Ziatkovskyi, L. O. Ligonenko, V. M. Oparin, K. V. Pavliuk, V. M. Rodionova, M. V. Romanovskyi, M. V. Rubakha, V. A. Slepov, V. V. Bocharov, V. V. Kovalev, J. Donaldson, S. Myers, J. S. Mill, and others. Disspite the wide range of scientific works on this subject, in our opinion, there remain problems that can't have unambiguous solutions due to the rapid development of the Ukrainian financial market, volatility of the regulatory framework, political instability, increased business risks, fierce competition and inclusive globalization. They require further research and improvement. These tasks include optimizing sources of financing for enterprises.

The aim of the article is studying sources of financing domestic enterprises, in particular, by economic activities; assessing the behavior of the volume and structure of financial resources of Ukrainian enterprises, their financial results; and searching for ways to optimize the formation and increase the efficiency of using financial resources of enterprises.

$\mathrm{T}$ he analysis of financial resources of Ukrainian enterprises should be started with the definition given in the financial dictionary: "Financial resources are funds available to enterprises, economic organizations and institutions" [1]. Based on the above, an improved definition of "financial resources" can be formed. This is part of the enterprise's money formed as a result of the distribution of the manufactured product, attracted by the enterprise from various sources and aimed at providing extended reproduction, maintenance and development of non-production facilities, consumption, and can be directed at creating reserves. Financial resources are one of the fundamental concepts of enterprise finance. They always act in monetary form, have a distributive character and reflect the formation and use of profit of business entities.

As we know, sources of formation of enterprise financial resources are their equity and borrowed funds. The equity capital describes the total value of the enterprise's assets that belong to it on the right of ownership, use and disposal, i.e. are owned by it and used to form part of the assets for indefinite term on a free-of-charge, irrevocable basis. The use of the enterprise's own financial resources has a number of advantages, in particular, providing a higher level of financial independence, liquidity and solvency, as well as profitability due to savings on the payment of the loan interest [2]. The borrowed funds are represented as short-term and long-term loans obtained on the financial market. Along with the possibility of unrestricted access to credit funds, as a positive side of the use of the borrowed capital, the conditions of obtaining them can be quite burdensome for business entities [3], and this fact reduces the interest in attracting financial resources of this kind.

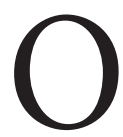
ne of the tasks of the financial policy of each enterprise is determination of the optimal balance between its own and attracted financial resources. It is accepted that the enterprise's own resources should prevail in the structure of financing its activities. It should be noted that this standard is conditional since the optimality of the ratio of equity and borrowed capital is determined by a number of factors, including the stage of development of the enterprise, the type of economic activity in which it is engaged and its development strategy.

Currently, many Ukrainian business entities have poor financial standing, lack financial resources to ensure reproduction on both an enlarged and a simple scale due to insufficient equity funds and inaccessibility of certain external sources of financing, as well as low efficiency of their use. That is why, to solve these problems, enterprises need to organize their financial resources effectively. For this purpose, the analysis of enterprise financial resources is used. It is an important element of the overall system of enterprise management, the system of ways for processing, transforming and using information to ensure competitiveness. In general, the analysis makes it possible to qualitatively evaluate management decisions, determine the completeness and reliability of information support for their justification, identify the possibility for and assess the risk of economic or financial maneuver, characterize the strategy and tactics of the business entity.

Therfore, it will be advisable to analyze the structure of financial resources of large and medium-sized enterprises in Ukraine (without regard to the results of activities of banks, budgetary institutions, the temporarily occupied territory of the Autonomous Republic of Crimea, the city of Sevastopol, and part of the temporarily occupied territories in Donetsk and Luhansk regions) by types of economic activity.

The study showed that as of March 31, 2019, the largest share of the public financial resources is accounted for by industry (44.83\%); wholesale and retail trade, repair of motor vehicles and motorcycles (19.75\%); transport, warehousing, postal and courier activities (13.4\%), and professional, scientific and technical activities $(9.43 \%)$. The smallest share of Ukraine's financial resources is concentrated in education $(0.02 \%)$; health care 
and social assistance (0.11\%); agriculture, forestry and fisheries $(0.2 \%)$; temporary accommodation and catering $(0.3 \%)$; art, sport, entertainment and recreation $(0.4 \%)$; provision of other services $(0.06 \%)$.

$\mathrm{I}$ n general, over the three years, the volume of financial resources has decreased in almost all economic sectors, including education (-19.4\%), professional, scientific and technical activities $(-18.2 \%)$, healthcare and social assistance (-17.8\%) (Tbl. 1). Only industry; wholesale and retail trade, repair of motor vehicles, motorcycles; and information and telecommunications still demonstrate a positive trend.

The analysis of the trends in the volume of finance of domestic enterprises showed that as of March 31, 2019 it increased by UAH328411.3 million compared to the same date in 2017, and decreased by UAH14034.5 million compared to 2018 .
Assessing sources of formation of financial resources deserves special attention since they are the economic basis of activities of enterprises. Thus, during the period under review, borrowed capital was the main source of the growth in financial resources. Its share, as of the end of March 2018, accounted for $69.6 \%$ of the total value of capital, while equity capital accounted for only $30.4 \%$ of the total value of capital. However, assessing the structure of capital of Ukrainian enterprises over the last year indicates a slight change, namely, a decrease in the weight of borrowed funds in the formation of financial resources. There observed an increase in the value of equity capital by $6.5 \%$, in particular, in the overall structure of capital of enterprises its share also increased by $0.4 \%$ ( Tbl. 2$)$.

The prevailing share of borrowed capital demonstrates the dependence of Ukrainian enterprises on attracted funds. Borrowed capital, in its turn, grows only due to current liabilities, which increased over the

Table 1

Trends in the structure of financing sources for large and medium-sized enterprises in Ukraine as of March 31, 2017-2019, UAH mln

\begin{tabular}{|c|c|c|c|c|c|c|c|}
\hline \multirow[b]{2}{*}{ Indicator } & \multicolumn{2}{|c|}{2017} & \multicolumn{2}{|c|}{2018} & \multicolumn{2}{|c|}{2019} & \multirow{2}{*}{$\begin{array}{l}\text { The growth rate } \\
\text { for the period } \\
2019 \text { to } 2017, \%\end{array}$} \\
\hline & $\begin{array}{l}\text { Amount, } \\
\text { UAH mln }\end{array}$ & $\begin{array}{c}\text { Share, } \\
\%\end{array}$ & $\begin{array}{l}\text { Amount, } \\
\text { UAH mln }\end{array}$ & $\begin{array}{c}\text { Share, } \\
\%\end{array}$ & $\begin{array}{l}\text { Amount, } \\
\text { UAH mln }\end{array}$ & $\begin{array}{c}\text { Share, } \\
\%\end{array}$ & \\
\hline Total capital, including: & 6243728.8 & 100.0 & 6586174.6 & 100.0 & 6572140.1 & 100.0 & 5.3 \\
\hline $\begin{array}{l}\text { - agriculture, forestry and } \\
\text { fisheries }\end{array}$ & 19361.2 & 0.31 & 15249.0 & 0.23 & 13084.0 & 0.2 & -32.4 \\
\hline - industry & 2619627.6 & 41.96 & 2915379.3 & 44.27 & 2945981.2 & 44.83 & 12.5 \\
\hline - construction & 172775.9 & 2.77 & 140652.1 & 2.14 & 154687.9 & 2.35 & -10.5 \\
\hline $\begin{array}{l}\text { - wholesale and retail trade; } \\
\text { repair of motor vehicles and } \\
\text { motorcycles }\end{array}$ & 1044985.9 & 16.74 & 1189724.2 & 18.06 & 1297962.4 & 19.75 & 24.2 \\
\hline $\begin{array}{l}\text { - transport, warehousing, } \\
\text { postal and courier activities }\end{array}$ & 995929.3 & 15.95 & 903177.9 & 13.72 & 880859.6 & 13.4 & -11.6 \\
\hline $\begin{array}{l}\text { - temporary accommodation } \\
\text { and catering }\end{array}$ & 18534.3 & 0.3 & 20398.1 & 0.31 & 20034.8 & 0.3 & 8.1 \\
\hline $\begin{array}{l}\text { - information and } \\
\text { telecommunications }\end{array}$ & 96136.0 & 1.54 & 109273.8 & 1.66 & 127163.9 & 1.94 & 32.3 \\
\hline $\begin{array}{l}\text { - financial and insurance } \\
\text { activities }\end{array}$ & 136082.5 & 2.18 & 141185.8 & 2.14 & 105262.2 & 1.6 & -22.6 \\
\hline - real estate transactions & 158144.9 & 2.53 & 175252.9 & 2.66 & 147160.5 & 2.24 & -6.9 \\
\hline $\begin{array}{l}\text { - professional, scientific and } \\
\text { technical activities }\end{array}$ & 757694.8 & 12.14 & 694691.0 & 10.55 & 619899.6 & 9.43 & -18.2 \\
\hline $\begin{array}{l}\text { - activities in the field of admi- } \\
\text { nistrative and support services }\end{array}$ & 187638.4 & 3.00 & 239403.9 & 3.63 & 221199.2 & 3.37 & 17.9 \\
\hline - education & 1968.5 & 0.03 & 2086.2 & 0.03 & 1585.9 & 0.02 & -19.4 \\
\hline $\begin{array}{l}\text { - health care and social } \\
\text { assistance }\end{array}$ & 9139.1 & 0.15 & 10606.7 & 0.16 & 7509.0 & 0.11 & -17.8 \\
\hline $\begin{array}{l}\text { - arts, sports, entertainment } \\
\text { and recreation }\end{array}$ & 22908.6 & 0.36 & 26563.7 & 0.4 & 26166.8 & 0.4 & 14.2 \\
\hline - provision of other services & 2801.8 & 0.04 & 2530.0 & 0.04 & 3583.1 & 0.06 & 27.9 \\
\hline
\end{tabular}

Source: developed by the authors based on [4]. 
Trends in the capital structure of large and medium-sized enterprises in Ukraine as of March 31, 2017-2019

\begin{tabular}{|l|c|c|c|c|c|}
\hline \multicolumn{1}{|c|}{ Indexes } & $\mathbf{2 0 1 7}$ & $\mathbf{2 0 1 8}$ & $\mathbf{2 0 1 9}$ & $\begin{array}{c}\mathbf{2 0 1 9} \text { vs 2017, } \\
\text { (+/-) }\end{array}$ & $\begin{array}{c}\text { The growth rate } \\
\text { for the period } \\
\mathbf{2 0 1 9} \text { to 2017, \% }\end{array}$ \\
\hline Total value of capital, UAH mln & 6243728.8 & 6586174.6 & 6572140.1 & 328411.3 & 5.3 \\
\hline Equity, UAH mln & 1905956.5 & 2002487.0 & 2028855.2 & 122898.7 & 6.5 \\
\hline \% of the total & 30.5 & 30.4 & 30.9 & 0.4 & - \\
\hline Borrowed capital, UAH mln & 4337772.3 & 4583687.6 & 4543284.9 & 205512.6 & 4.7 \\
\hline \% of the total & 69.5 & 69.6 & 69.1 & -0.4 & - \\
\hline
\end{tabular}

Source: developed by the authors based on [4].

period under review from UAH3175358.3 million to UAH3517787.3 million. The share of long-term liabilities decreased during the period from UAH1162269.3 million to UAH1025482.3 million.

To study the status of business entities, it is not sufficient to have only the data on the structure of financial resources since they don't reflect the level of efficiency of their use. For this purpose, it is necessary to analyze the financial results of enterprises and compare them with the structure of their financial resources (Fig. 1).

T financial results are positive, it indicates the possibility of borrowing funds and payments for liabilities. As can be seen from Figure 1, the financial performance of Ukrainian enterprises in absolute terms demonstrates a positive trend. Losses in the period 2013-2016 were replaced by increasing profits of large and medium-sized domestic enterprises. At the same time, a significant numper of enterprises are operating at a loss, which indicates inefficient use of their equity funds and results in impossibility of borrowing and difficulties with the repay- ment of interest on loans. The mentioned conditions have a negative impact on innovation and investment.

Therefore, the formation of structure of financial resources should provide such a combination of equity and borrowed capital that will contribute to an increase in return on capital, solvency, financial stability; decrease in financial risks and the weighted average cost of capital, etc [6].

Under modern economic conditions, the optimization of sources of financial resources for Ukrainian enterprises should be based on the criteria of their sufficiency, optimality of their correlation depending on the industry characteristics and specific conditions of management, economic feasibility of their involvement and efficiency.

Currently, grant programs are operating in Ukraine, in particular, COSME, Horizon 2020, whose activities focus on the needs of small and medium-sized businesses, but domestic entrepreneurs do not yet have sufficient experience to participate in these programs. Also in Ukraine projects of international financial institutions that provide both financial (credit) and consulting sup-

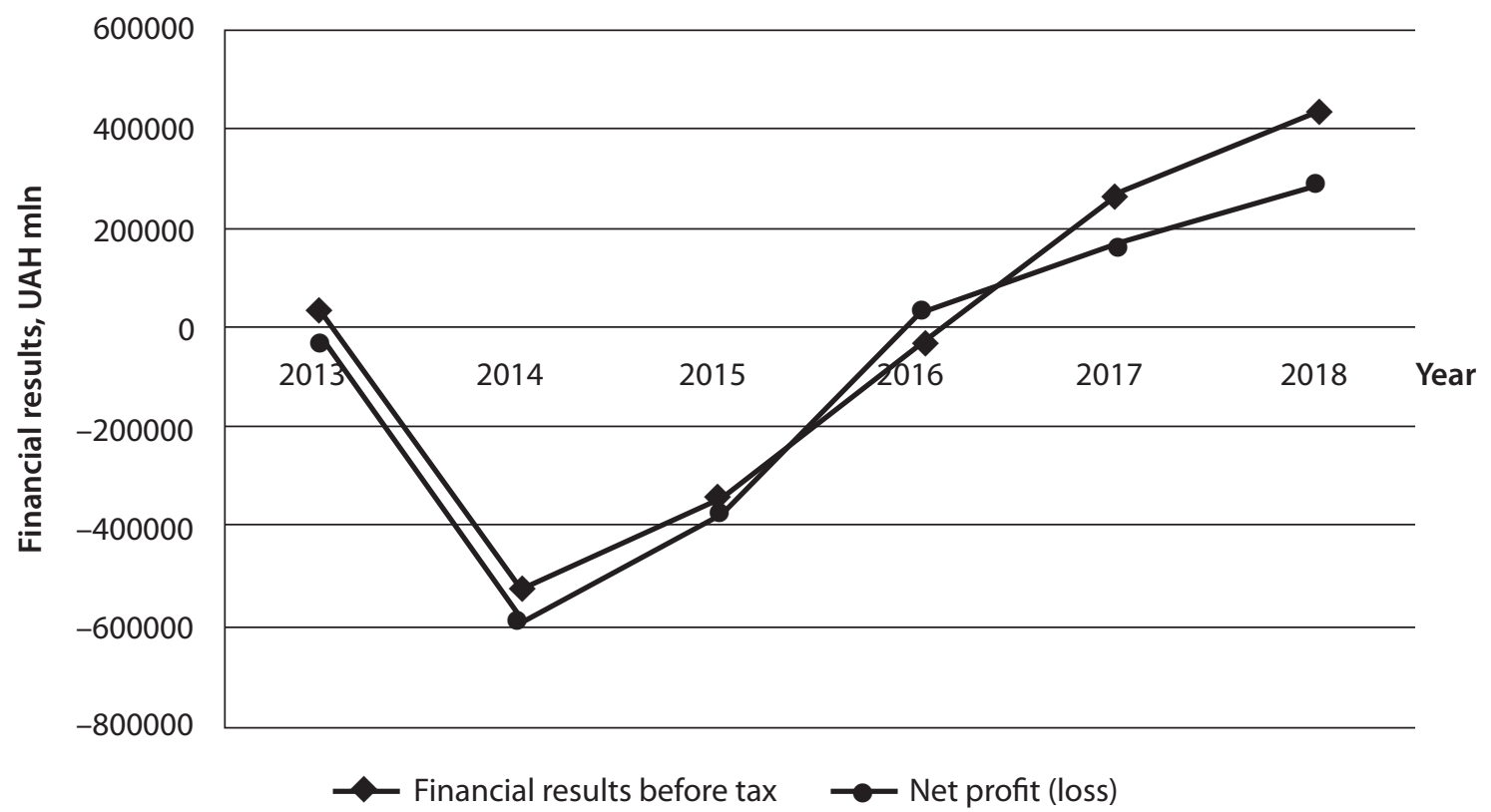

Fig. 1. Financial results of large and medium-sized enterprises by type of economic activity Source: developed by the authors based on $[4 ; 5]$. 
port are being implemented. An important tool for attracting these resources to domestic small and mediumsized businesses is informing about these opportunities and helping to formulate grant and loan applications [7].

\section{CONCLUSIONS}

We share the opinion of V. Yu. Badakovskyi that among the most important problems in forming financial resources are the low investment attractiveness of individual enterprises; use of outdated technologies; significant deterioration of fixed assets; scarcity of resources to finance activities of the enterprise, which results in low competitiveness of enterprises; inability to determine clearly the impact of the tax system on forming the optimal structure of sources of financial resources [8]; low level of financial transparency for investors and creditors; imperfect training of managers; lack of a comprehensive system of financial management of enterprises.

In order to enhance optimizing sources of formation of financial resources for an enterprise, the following ways can be proposed: improving the skills of employees responsible for managing the finances of enterprises; development of qualitatively new approaches to organization of work in the sphere of enterprise financing; formation of information support necessary for enterprises; selection of effective sources of attracting financial resources by calculating the cost of attracting resources from each of the sources; providing enterprises with the necessary amounts of financial resources for their needs; improving the structure of financial resources; ensuring control over the state of financial resources to assess the impact of the quality of financial resources management on the level of profitability and trends in the development of enterprises.

Successful implementation of the proposed ways to improve financial activities of enterprises requires appropriate measures at the national level. Among those that will contribute to positive changes in the capital structure of enterprises, the activation of their financial activities there can be mentioned: creating a political environment that will positively affect the development of small and medium-sized businesses as well as a favorable investment climate, which will increase investment in business and activate financial activities of business entities in the country; promoting the development of an effective regional business infrastructure that will provide information, advisory, and training services on financial activities; assessing the state of development of business entities in the region and elaborating measures for development of entrepreneurship on preferential terms in less developed areas. It would be also appropriate to elaborate programs to promote the development of business entities at different levels of government; promoting the development of a system for training highly qualified personnel for financial sphere, improving the qualification of personnel through their retraining, interning abroad; conducting social surveys of entrepreneurs on the issues of assessing the investment climate, informing entrepre- neurs about positive foreign experience of functioning of enterprises.

$\mathrm{T}$ Thus, the transition of Ukraine to market economy actualizes the problems of improving approaches to managing financial resources and optimizing their use. Given the fact that among the instruments applied in management of financial resources a special role should be played by progressive methods, their totality should be used to influence the formation of such proportions of equity and borrowed funds of the enterprise, which will provide an additional increase in profitability of its equity capital, and, most importantly, create favorable conditions for the financial stability of the organization for the future.

\section{LITERATURE}

1. Моляков Д. С. Финансы предприятий отраслей народного хозяйства. М. : Финансы и статистика, 2014. 200 с.

2. Рубаха М. В. Методи мобілізації фінансових ресурсів суб'єктами господарювання на фінансовому ринку України. Актуальні проблеми розвитку економіки регіону. 2017. Вип. 7. Т. 1. С. 122-130.

3. Близнюк О. П., Горпинченко А. П. Класифікація джерел формування фінансових ресурсів підприємства. Bicник Міжнародного слов'янського університету. Серія «Економічні науки». 2012. Т. 15. № 2. С. 52-58.

4. Показники балансу великих та середніх підприємств за видами економічної діяльності URL: http:// www.ukrstat.gov.ua/operativ/operativ2019/fin/sbp/sbp_u/ sbp_219_u.htm (дата звернення 07.08.2019).

5. Статистична інформація Державної служби статистики. URL: http://www.ukrstat.gov.ua (дата звернення 07.08.2019).

6. Дропа Я. Б., Терешко О.М. Формування фінансових ресурсів підприємств в сучасних умовах розвитку фінансової системи // Тези IV Міжнародної науково-практичної конференції «Формування ефективної моделі розвитку підприємства в умовах ринкової економіки». Житомир, 2016. URL: https://conf.ztu.edu.ua/wp-content/uploads/2017/01/60-1.pdf

7. Ясіновська І., Козак С. Фінансові інструменти та проблеми залучення фінансових ресурсів у малий та середній бізнес в Україні. Сталий розвиток економіки. 2018. № 1. С. 67-73.

8. Бадаковський В. Ю. Проблеми залучення кредитних ресурсів вітчизняними підприємствами. Фінанси України. 2015. № 1. С. 106-112.

\section{REFERENCES}

Badakovskyi, V. Yu. "Problemy zaluchennia kredytnykh resursiv vitchyznianymy pidpryiemstvamy" [Problems of attracting credit resources by domestic enterprises]. Finansy Ukrainy, no. 1 (2015): 106-112.

Blyzniuk, O. P., and Horpynchenko, A. P. "Klasyfikatsiia dzherel formuvannia finansovykh resursiv pidpryiemstva" [Classification of sources of formation of financial resources of the enterprise]. Visnyk Mizhnarodnoho slovianskoho universytetu. Seriia «Ekonomichni nauky», vol. 15, no. 2 (2012): 52-58. 
Dropa, Ya. B., and Tereshko, O. M. "Formuvannia finansovykh resursiv pidpryiemstv $v$ suchasnykh umovakh rozvytku finansovoi systemy" [Formation of financial resources of enterprises in modern conditions of development of financial system]. Formuvannia efektyvnoi modeli rozvytku pidpryiemstva v umovakh rynkovoi ekonomiky. 2016. https://conf.ztu.edu.ua/ wp-content/uploads/2017/01/60-1.pdf

Molyakov, D. S. Finansy predpriyatiy otrasley narodnogo khozyaystva [Finances of enterprises of the branches of economy]. Moscow: Finansy i statistika, 2014.

"Pokaznyky balansu velykykh ta serednikh pidpryiemstv za vydamy ekonomichnoi diialnosti" [Balance indicators of large and medium-sized enterprises by types of economic activity]. http://www.ukrstat.gov.ua/operativ/operativ2019/fin/ sbp/sbp_u/sbp_219_u.htm
Rubakha, M. V. "Metody mobilizatsii finansovykh resursiv subiektamy hospodariuvannia na finansovomu rynku Ukrainy" [Methods of mobilization of financial resources by economic entities in the financial market of Ukraine]. Aktualni problemy rozvytku ekonomiky rehionu, vol. 1, no. 7 (2017): 122-130.

"Statystychna informatsiia Derzhavnoi sluzhby statystyky" [Statistical information of the State Statistics Service]. http://www.ukrstat.gov.ua

Yasinovska, I., and Kozak, S. "Finansovi instrumenty ta problemy zaluchennia finansovykh resursiv u malyi ta serednii biznes v Ukraini" [Financial instruments and problems of attracting financial resources to small and medium-sized businesses in Ukraine]. Stalyi rozvytok ekonomiky, no. 1 (2018): 67-73.

\title{
АНАЛІЗ ДІЯЛЬНОСТІ ГОЛОВНОГО УПРАВЛІННЯ ПЕНСІЙНОГО ФОНДУ УКРАЇНИ В ДНІПРОПЕТРОВСЬКІЙ ОБЛАСТІ
}

\author{
๑2019 ТАРЛОПОВ І. 0.
}

УДК 331.25:33.021.8

JEL: G28; 138; J26

Тарлопов І. О. Аналіз діяльності Головного управління Пенсійного фонду України в Дніпропетровській області

Метою статті є аналіз діяльності бюджетної установи на прикладі Головного управління Пенсійного фонду України в Дніпропетровській області та надання пропозицій щодо розвитку установи. здійснено вертикальний і горизонтальний аналіз активів та джерел формування майна ГУ ПФУ в Дніпропетровській області за період 2015-2017 рр. Побудовано схему джерел надходження до Пенсійного фонду України за сьома напрямами відповідно до діючого законодавства. Згідно з цією схемою проаналізовано доходи та видатки Головного управління Пфу в Дніпропетровській області за джерелами надходження за 2013-2017 рр. Обгрунтовано причини щорічного збільшення витрат Головного управління Пфу в Дніпропетровській області насамперед за рахунок демографічних процесів. Доведено, що наразі суттєвою та невирішеною проблемою пенсійної системи залишається дефіцит бюджету Пфу, що унеможливлює ефективне та продуктивне керівництво такою установою. Як наслідок, наявність даної проблеми загрожує фінансовій стабільності найбільш незахищеної частини населення - людей похилого віку, а також призводить до підвищення незадоволеності та зниження продуктивності працездатного населення, що невпевнені у своєму майбутньому.

Ключові слова: бюджетна установа, видатки, кошторис, джерела формування, демографічна криза.

DOl: https://doi.org/10.32983/2222-4459-2019-9-264-271

Рис.: 3. Табл.: 4. Бібл.: 8.

Тарлопов Ігор Олегович - кандидат економічних наук, доцент, доцент кафедри статистики, обліку та економічної інформатики, Дніпровський національний університет імені Олеся Гончара (просп. Гагаріна, 72, Дніпро, 49010, Україна)

E-mail: tarlopovio@gmail.com

\section{УДК 331.25:33.021.8} JEL: G28; 138; J26

Тарлопов И. О. Анализ деятельности Главного управления Пенсионного фонда Украины в Днепропетровской области Целью статьи является анализ деятельности бюджетного учреждения на примере Главного управления Пенсионного фонда Украины в Днепропетровской области и предоставление предложений по развитию учреждения. Осуществлен вертикальный и горизонтальный анализ активов и источников формирования имущества ГУ ПФУ в Днепропетровской области за период 2015-2017 г2. Построена схема источников поступления в Пенсионный фонд Украины по семи направлениям в соответствии с действующим законодательством. Согласно этой схеме проанализированы доходы и расходы Главного управления Пфу в Днепропетровской области по источникам поступления за 2013-2017 г2. Обоснованы причины ежегодного увеличения расходов Главного управления Пфу в Днепропетровской области прежде всего за счет демографических прочессов. Доказано, что в настоящее время существенной и нерешенной проблемой пенсионной системы остается дефицит бюджета Пфу, что делает невозможным эффективное и продуктивное руководство таким учреждением. Как следствие, наличие данной проблемы угрожает финансовой стабильности наиболее незащищенной части населения - пожилых людей, а также приводит
UDC 331.25:33.021.8 JEL: G28; 138; J26

Tarlopov I. O. Analyzing the Activities of the General Directorate of the Pension Fund of Ukraine in the Dnipropetrovsk Region The article is aimed at analyzing the activities of budgetary institution on the example of the General Directorate of the Pension Fund of Ukraine in the Dnipropetrovsk region and providing proposals for development of the institution. A vertical and a horizontal analysis of the assets and sources of the property formation of the GD PFU in the Dnipropetrovsk region for the time period of 2015-2017 is carried out. A scheme of sources of income to the Pension Fund of Ukraine in seven directions in accordance with the current legislation has been built. According to this scheme, the revenues and expenses of the General Directorate of the PFU in the Dnipropetrovsk region are analyzed by the sources of income for 2013-2017. The reasons for the annual increase in expenditures of the General Directorate of the PFU in the Dnipropetrovsk region are substantiated primarily due to demographic processes. It is proved that the current significant and unresolved problem of the pension system remains the budget deficit of the PFU, which makes it impossible to efficiently and productively administrate such an institution. As a result, the problem threatens the financial stability of the most vulnerable part of the population, the elder people, as well as causes increasing dissatisfaction and reduction 